\title{
EDUCATIONAL ROBOTICS IN THE EDUCATION AT BASIC SCHOOLS IN THE CZECH REPUBLIC
}

\author{
Jan BA
}

Přijato: 16. 11. 2017 / Akceptováno: 5. 3. 2018

Typ článku: Výzkumná studie

DOI: $10.5507 /$ jtie.2018.001

Abstract: The aim of our research was to map and describe the current condition of the education of educational robotics in the Czech Republic before the planned curriculum changes in technical education. We tried to find out if teachers use robotic kits in their lessons, in what subjects they use the kits and how. Furthermore, we asked them what problems they face in the process of integrating the robotic kits into the lessons. We carried out a questionnaire survey among teachers throughout the Czech Republic. From the results follow that educational robotics is the most frequently used within free time activities and as for the school subject it is used in informatics even if there are a plenty of noncertificated teachers. To main problems which disable the integration of educational robotics into education belong the absence of algorithms and programming in the curriculum for basic schools and insufficient school finance for their buying.

Key words: educational robotics, robotic kit, basic school, teacher.

\section{EDUKAČNÍ ROBOTIKA VE VÝUCE NA ZÁKLADNÍCH ŠKOLÁCH V ČESKÉ REPUBLICE}

Abstrakt: Cílem našeho výzkumu bylo zmapovat a popsat současný stav výuky edukačni robotiky v České republice pred chystanými kurikulárními změnami $v$ technickém vzdělávání. Zjištovali jsme, zda učitelé využivají ve výuce robotické stavebnice, ve kterých predmětech je použivaji, jakým způsobem a na jaké problémy v souvislosti s jejich začleněním do výuky narážejí. Zrealizovali jsme proto dotaznikové šetřeni mezi učiteli v České republice. Z výsledkủ vyplývá, že edukačni robotika je nejčastěji využivána $v$ rámci volnočasových aktivit, ze školnich předmětů poté nejčastěji ve výuce informatiky, a to i přes existenci řady neaprobovaných učitelů pro výuku tohoto predmětu. Nejčastějšimi problémy znemožňujicími začleněni edukačni robotiky do výuky jsou dle našich respondentů absence algoritmizace a programování v kurikulu pro základni školy a nedostatečné finance pro pořizení robotických stavebnic.

Klíčová slova: edukační robotika, robotická stavebnice, základní škola, učitel.

*Autor pro korespondenci: hanzi23@kvd.zcu.cz 


\section{1 Úvod}

V České republice byla v roce 2014 vládou schválena Strategie digitálního vzdělávání do roku 2020 (dále jen SDVZ), která zavádí seznam intervencí, které umožní lepší vzdělávání v prostředí, které se v současnosti rychle mění zejména vlivem digitálních technologií. V SDVZ se uvádí, že dle provedených výzkumů jsou digitální technologie používány učiteli v České republice primárně pro přípravu výuky, podstatně méně poté přímo ve vyučování. Autoři sami ovšem přiznávají, že jedním z hlavních důvodů je fakt, že naše kurikulární dokumenty účelné využití digitálních technologií v podstatě nepodporují (MŠMT, 2014).

SDVZ má stanoveny tři základní priority, mezi které patří snižování nerovnosti ve vzdělávání, podpora kvalitní výuky a učitele jako jejího předpokladu a odpovědné a efektivní řízení vzdělávacího systému (MŠMT, 2014).

$\mathrm{V}$ tomto příspěvku se podrobněji zaměříme na druhou $\mathrm{z}$ těchto priorit - podporu kvalitní výuky a učitele jako jejího předpokladu. Konkrétně se věnujeme učitelům, kteří v současné době zavádějí do výuky prvky edukační robotiky s využitím robotických stavebnic, které jsou v SDVZ zmiňovány jako jedna z možných pomůcek pro rozvoj digitální gramotnosti a informatického myšlení. V př́ispěvku popíšeme profil učitele, v kterých předmětech se edukační robotice věnují, jakým způsobem ji aplikují a také jaké jsou v současnosti největší problémy, které jim znemožňují její začleňování do výuky. Naším cílem je popsat aktuální způsob využívání prvků edukační robotiky ve výuce a zároveň poukázat na současné problémy v procesu začleňování robotických stavebnic do výuky a přispět tak $\mathrm{k}$ diskusi kurikulární změny.

Edukační robotika je oblast, která je úzce propojená s pedagogikou a využívá roboty jako prostředky pro plnění vzdělávacích cílů (Tocháček \& Lapeš, 2012). Robota můžeme chápat a aplikovat ve výuce různě. Může se stát objektem studia, jakožto fyzický hardware. Můžeme jej ale také chápat jako prostředek poznání mnohých principů a jevů. V neposlední řadě také jako prostředek výuky, rozvoje a výchovy studentů (Ospennikova, Ershov, \& Iljin, 2015). Využití edukační robotiky ve vzdělávání nemusí být v žádném případě úzce spjato $\mathrm{s}$ jedním předmětem nebo konkrétní výukovou oblastí. Zařadit edukační robotiku lze jak do „intra-kurikulární“ oblasti, tedy př́imo do školního kurikula různých předmětů, tak i do ,extra-kurikulárni““ oblasti, která zahrnuje volnočasové aktivity a kroužky (Mubin, Stevens, Shahid, Al Mahmud, \& Dong, 2013). Využívána je jako prostředek pro rozvoj informatického myšlení a programování (Eguchi, 2014; Atmatzidou \& Demetriadis, 2014) či k rozvoji schopností řešení problémů (Lindh \& Holgersson, 2007). Žákům může napomoci při učení nových slov při výuce jazyků, demonstrovat různé jevy při výuce fyziky a př́rodních věd (Williams, Ma, Prejean, \& Ford, 2007), podávat vizuální zpětnou vazbu během výuky programování (Mubin, Stevens, Shahid, Al Mahmud, \& Dong, 2013) či rozvíjet schopnosti řešení problémů v matematice (Hussain, Lindh, \& Shukur, 2006). V zahraničí je edukační robotika běžně využívána v různých modifikacích v předmětech z oblasti STEM (Eguchi \& Uribe, 2017; Kim, Kim, Yuan, Hill, Doshi, \& Thai, 2015). Nejedná se pouze o běžně dostupné roboty a stavebnice, ale i různé modifikace (Ziaeefard, Miller, Rastgaar \& Mahmoudian, 2017). Výzkum mapující využití edukační robotiky mezi učiteli v České republice ovšem v současnosti neexistuje. 


\section{Metodologie}

Pro zmapování aktuální situace učitelů využívajících edukační robotiku ve výuce na základních školách jsme použili metodu dotazníkového šetření. Technická realizace a sběr dat byl prováděn pomocí cloudové aplikace Google Formuláře, která zcela vyhovovala požadavkům testování. Distribuce dotazníku probíhala prostřednictvím e-mailu, který byl vždy směřován vedení školy (ředitelům či jejich zástupcům) s prosbou o přímé vyplnění (pokud se jednalo o ředitele či ředitelku zajímající se o robotické stavebnice) či předání učitelům, kteří mají k této problematice bližší vztah. Vyplnění dotazníku bylo zcela anonymní. Většina otázek v dotazníku byla povinná, což znamená, že respondent musel na otázku odpovědět, jinak nebylo možné přejít na další sekci otázek. Pouze dvě otázky byly nepovinné. Jednalo se o otázky, u kterých bylo jisté riziko, že ne všichni respondenti na ně budou schopni relevantně odpovědět.

Dotazník byl rozdělen do tři částí. Každá část obsahovala vlastní sekci otázek. Mezi sekcemi bylo poté odkazováno na základě odpovědi respondenta. První část dotazníku obsahovala pouze jedinou otázku, a to, zda respondent aktivně využívá robotickou stavebnici ve výuce. $\mathrm{Na}$ základě toho, zda byla odpověd' pozitivní či negativní, byla respondentovi předložena další část dotazníku s rozdílnými otázkami. V sekci otázek určené pro učitele věnující se edukační robotice byly obsaženy polouzavřené či uzavřené otázky zaměřené např́íklad na zmapování předmětů s využitím edukační robotiky, způsobu využití, hodinovou dotaci, typ robotické stavebnice a programovacího prostředí, metodické materiály a metodickou podporu a typy robotických aktivit. Respondenti, kteří robotické stavebnice ve výuce nevyužívají, odpovídali na odlišnou baterii otázek, ve které byly obsaženy otázky zaměřené na zjištění důvodů nevyužívání edukační robotiky ve výuce. Závěrečná část dotazníku byla věnována charakteristice respondentů a byla pro obě skupiny respondentů společná.

$\mathrm{Na}$ konci ř́jna 2016 proběhlo pilotní testování dotazníku na skupině deseti respondentů, po kterém bylo teprve přistoupeno k distribuci dotazníku na školy. Samotné dotazníkové šetření poté proběhlo v období od listopadu 2016 do ledna 2017.

Cílovou skupinou dotazníku byli učitelé druhého stupně základních škol a odpovídajících ročníků víceletých gymnázií v České republice. Ze seznamu všech školských institucí jsme nejprve vyřadili dětské domovy, školy fungující při nemocnicích či diagnostické ústavy. Následně jsme oslovili celkem 3911 škol ve všech krajích ČR a získali jsme 360 odpovědí, z nichž 356 bylo od učitelů druhého stupně základních škol a 4 od učitelů z víceletých gymnázií. Návratnost dotazníku tedy činila 9,2\%. Celkem 49 respondentů uvedlo, že se edukační robotice aktivně věnuje, zbylých 311 respondentů robotické stavebnice $\mathrm{z}$ různých důvodů nevyužívá. 


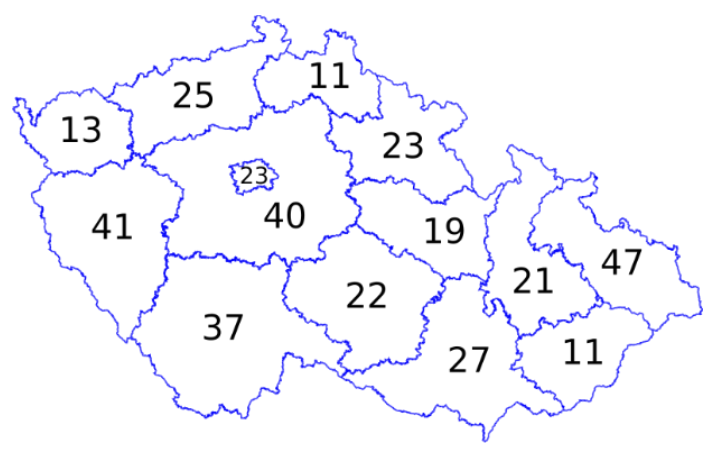

Obrázek č. 1: Rozložení respondentů do jednotlivých krajů ČR v závislosti na umístění školy (zdroj: vlastni).

\section{Výsledky výzkumu}

$\mathrm{V}$ tomto př́íspěvku představíme pouze část získaných výsledků. Jedná se o data charakterizující učitele využívající robotické stavebnice ve výuce v České republice. Jedná se o již zmíněných 49 respondentů, mezi kterými je 35 mužů a 14 žen.

Z grafu č. 1 je patrné, že nejčastěji se práci s robotickou stavebnicí věnují učitelé středního věku, kteří jsou rozvrstveni do všech krajů ČR (viz graf č. 2).

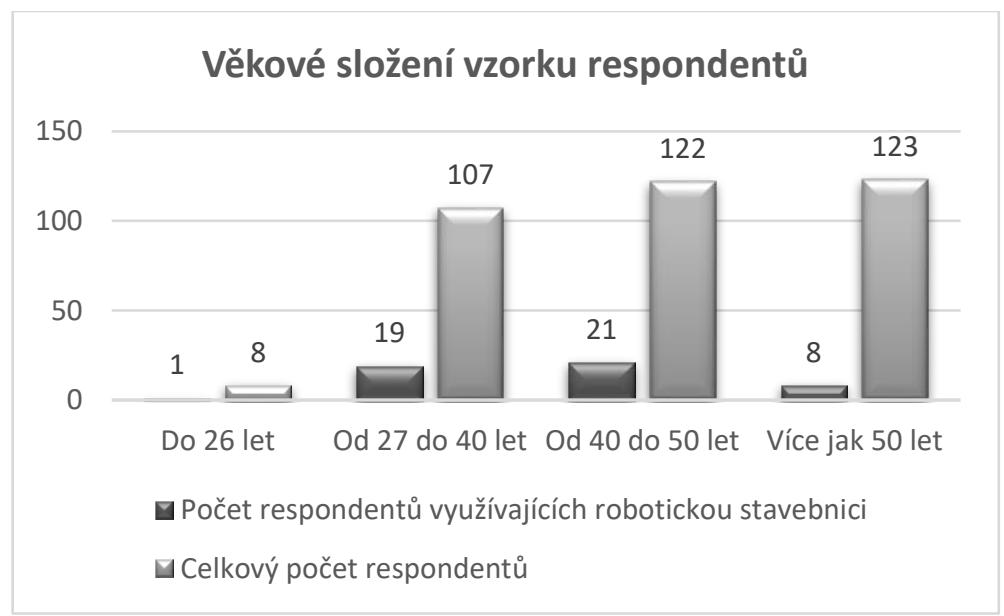

Graf č. 1: Věkové složení respondentů (zdroj: vlastní). 


\section{Počet respondentů využívajících ve výuce prvky edukační robotiky v jednotlivých krajích ČR}

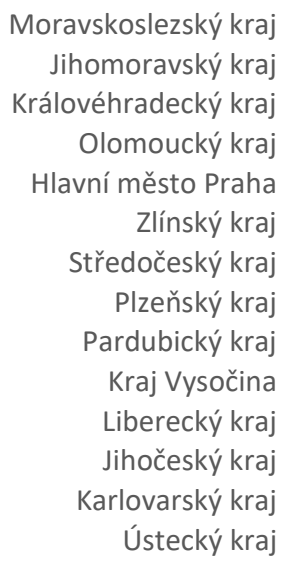

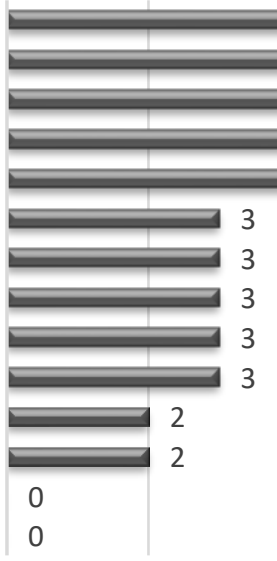

0

\section{(1)} .

\section{.}

(1)

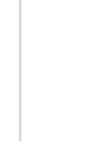

Graf č. 2: Respondenti využívajici prvky edukační robotiky ve výuce v rámci jednotlivých krajů České republiky (zdroj: vlastni).

Délka pedagogické praxe této skupiny respondentů (viz graf č. 3) je různorodá, nejčastěji ovšem delší než 10 let. Ve vzorku respondentů je zhruba pětina těch, které můžeme považovat za začínající učitele (s praxí do 5 let).

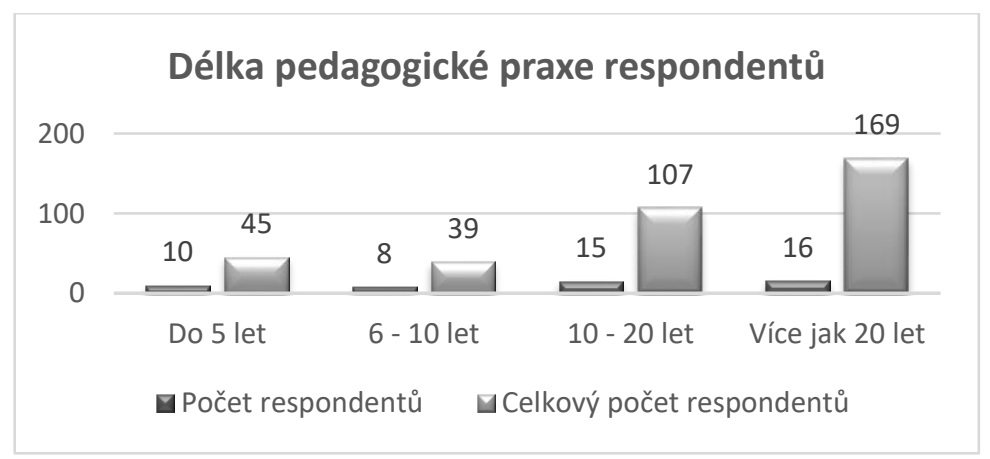

Graf č. 3: Délka pedagogické praxe respondenti̊ věnujících se výuce s robotickou stavebnici (zdroj: vlastni). 
Robotické stavebnice nezařazují do výuky pouze učitelé ve větších městech, ale také v menších městech a na vesnicích (viz tabulka č. 1).

\begin{tabular}{|c|c|c|}
\hline Velikost obce/města & Četnost respondentů & $\begin{array}{c}\text { Četnost respondentů } \\
\text { v \% }\end{array}$ \\
\hline Do 1000 obyvatel & 3 & $6,12 \%$ \\
\hline Od 1000 do 5000 obyvatel & 11 & $22,45 \%$ \\
\hline Od 5000 do 20 000 obyvatel & 10 & $20,41 \%$ \\
\hline Od 20 000 do 100 000 obyvatel & 14 & $28,57 \%$ \\
\hline Nad 100 000 obyvatel & 11 & $22,45 \%$ \\
\hline Celkem & $\mathbf{4 9}$ & $\mathbf{1 0 0} \%$ \\
\hline
\end{tabular}

Tab. č. 1: Počet respondentů využivajících robotickou stavebnici ve výuce z pohledu velikosti města, ve kterém se škola nachází.

Nejčastější předmět vyučovaný našimi 49 respondenty, kteří využívají edukační robotiku v didaktickém procesu je informatika či informační a komunikační technologie (dále jen ICT). Jedná se celkem o 37 respondentů. V 19 př́ípadech se jedná o učitele, který nemá vystudovanou aprobaci pro výuku informatiky nebo ICT, což svědčí o nedostatku absolventů učitelství informatiky pro základní školy. Tabulka č. 2 navíc uvádí vztah těchto respondentů k oblasti ICT.

\begin{tabular}{|c|c|c|}
\hline $\begin{array}{c}\text { Aprobovanost } \\
\text { pro výuku ICT }\end{array}$ & Vztah k ICT & Četnost \\
\hline \multirow{2}{*}{ ANO } & $\begin{array}{c}\text { Snažím se v této oblasti neustále zdokonalovat a } \\
\text { sledovat novinky v této oblasti. }\end{array}$ & 18 \\
\hline \multirow{2}{*}{ NE } & $\begin{array}{c}\text { Zajímám se o ICT, ale na škole ICT vyučuji z } \\
\text { důvodu nedostatku aprobovaných učitelů. }\end{array}$ & 3 \\
\cline { 2 - 4 } & $\begin{array}{c}\text { Nezajímám se o ICT, na škole ICT vyučuji } \\
\text { z důvodu nedostatku aprobovaných učitelů. }\end{array}$ & 1 \\
\cline { 2 - 4 } & $\begin{array}{c}\text { Hluboce se zajímám o ICT a sleduji objevující se } \\
\text { novinky pro zkvalitnění výuky. }\end{array}$ & 15 \\
\hline & Celkem & $\mathbf{3 7}$ \\
\hline
\end{tabular}

Tab. č. 2: Přehled aprobovaných a neaprobovaných respondentů vyučujicich předmèt informatika (ICT) a jejich vztah k oblasti ICT.

Mnohdy jsou tito učitelé zároveň vedoucími volnočasových kroužků. Tyto aktivity jsou také nejčastějším místem využití robotických stavebnic. Kromě informatiky nalezneme početnější zastoupení ještě $\mathrm{v}$ hodinách technické výchovy a fyziky. Na řadě škol existuje př́mo předmět robotika. Často jako volitelný, méně často také jako povinný (více viz tabulka č. 3). 


\begin{tabular}{|c|c|}
\hline $\begin{array}{c}\text { Předměty s využitím robotické } \\
\text { stavebnice }\end{array}$ & Četnost předmětu \\
\hline Volnočasové aktivity a kroužky & 31 \\
\hline Informatika a ICT & 19 \\
\hline Robotika & 17 \\
\hline Technická výchova & 10 \\
\hline Fyzika & 7 \\
\hline Specializovaná informatika & 1 \\
\hline Výtvarná výchova & 1 \\
\hline Chemie & 1 \\
\hline Zeměpis & 1 \\
\hline Matematika & 1 \\
\hline
\end{tabular}

Tab. č. 3: Využivání robotické stavebnice v různých předmètech.

Způsob využití robotické stavebnice učiteli se liši předmět od předmětu. Ve výuce informatiky (ICT) se učitelé zaměřují hlavně na výuku programování a algoritmizace. V technické výchově má naopak největší zastoupení konstruování a rozvoj jemné motoriky žáků. Na tyto činnosti jsou zpravidla zaměřené také volnočasové kroužky. Podrobnější informace o využití robotických stavebnic $\mathrm{v}$ pěti nejčastěji uváděných předmětech poskytuje tabulka č. 4 .

\begin{tabular}{|l|c|c|c|c|c|}
\hline \multirow{2}{*}{$\begin{array}{c}\text { Způsob využití } \\
\text { robotické stavebnice }\end{array}$} & \multicolumn{5}{|c|}{ Četnost začlenění činností do jednotlivých předmětů } \\
\cline { 2 - 6 } & Kroužky & ICT & Robotika & $\begin{array}{c}\text { Technická } \\
\text { výchova }\end{array}$ & Fyzika \\
\hline Výuka algoritmizace & 13 & 14 & 9 & 4 & 5 \\
\hline Výuka programování & 24 & 19 & 13 & 6 & 6 \\
\hline $\begin{array}{l}\text { Seznámení } \\
\text { s fungováním různých } \\
\text { technologií }\end{array}$ & 18 & 10 & 10 & 6 & 5 \\
\hline $\begin{array}{l}\text { Řešení matematických } \\
\text { úloh zábavnou formou }\end{array}$ & 2 & 2 & 1 & 1 & 1 \\
\hline $\begin{array}{l}\text { Rešení úloh a provádění } \\
\text { měřní pomocí senzorů }\end{array}$ & 9 & 8 & 7 & 4 & 5 \\
\hline $\begin{array}{l}\text { Rozvoj jemné motoriky } \\
\text { a schopností } \\
\text { konstruování }\end{array}$ & 28 & 14 & 15 & 9 & 6 \\
\hline $\begin{array}{l}\text { Př́íprava na robotické } \\
\text { soutěže }\end{array}$ & 11 & 6 & 8 & 7 & 3 \\
\hline
\end{tabular}

Tab. č 4: Primární zpưisoby využití robotické stavebnice v pěti respondenty nejčastěji vyučovaných predmětech. 
Nejčastěji jsou pro edukační robotiku využívané robotické stavebnice známé dánské firmy LEGO, a to jak novější verze EV3, tak i starší verze NXT. V 10 případech vyučující používá kombinaci těchto dvou stavebnic. Třetí nejčastěji uváděnou stavebnicí, ovšem uvedenou pouze v 6 prrípadech, je robotická verze české stavebnice Merkur. Více informací je obsaženo v tabulce č. 5 .

\begin{tabular}{|l|c|}
\hline Typ robotické stavebnice & Četnost využívání \\
\hline LEGO Mindstorms EV3 & 30 \\
\hline LEGO Mindstorms NXT & 24 \\
\hline Merkur & 6 \\
\hline LEGO WeDo 2.0 & 2 \\
\hline Arduino & 2 \\
\hline Fischertechnik & 1 \\
\hline H\&S Robotic Systems & 1 \\
\hline Robo Robo & 1 \\
\hline Make Block & 1 \\
\hline
\end{tabular}

Tab. č. 5: Typy robotických stavebnic využivané respondenty.

Z odpovědí získaných od 311 respondentů, kteří edukační robotiku ve výuce nevyužívají, je zajímavý především přehled pěti nejčastěji uváděných důvodů (viz tabulka č. 6) vedoucích $\mathrm{k}$ jejímu nezařazení do výuky. Mezi těmito respondenty se nalézá 140 mužů a 171 žen.

Nejčastějším důvodem nezařazení stavebnic do výuky je fakt, že se vyučující ve svém předmětu nevěnuje ani algoritmizaci, ani programování, a proto nevidí důvod $\mathrm{v}$ tom, proč by stavebnici do výuky měl zařadit. Druhý nejčastější důvod absence robotických stavebnic ve výuce je nedostatek financí. Vyučující by sice rádi robotické stavebnice ve výuce používali, ovšem škola nemá na jejich pořízení dostatek finančních prostředků. Řada učitelů nemá o robotických stavebnicích př́ilišné povědomí nebo o jejich využití zatím ani neuvažovali. Často také neví, jak s takovou výukou naložit a kde získat informace, které jim v počátcích situaci usnadní. Objevují se ale školy, které v současné době pořízení stavebnic plánují a s výukou edukační robotiky tak v blízké době začnou. Dá se tedy očekávat její další rozšíření a rozvoj. 


\begin{tabular}{|l|c|}
\hline \multicolumn{1}{|c|}{ Důvody nevyužívání stavebnic } & $\begin{array}{c}\text { Četnost uváděných } \\
\text { odpovědí }\end{array}$ \\
\hline Programování ani algoritmizaci se ve výuce nevěnujeme & 129 \\
\hline $\begin{array}{l}\text { Rád/a bych, ale problémem je nedostatek financí na pořízení } \\
\text { stavebnic }\end{array}$ & 125 \\
\hline Zatím jsem o využívání stavebnice neuvažoval/a & 90 \\
\hline Nemám s robotickými stavebnicemi dostatek zkušeností & 83 \\
\hline Nevím, jak s takovou výukou začít a jak ji uchopit & 72 \\
\hline Nevím, nepřemýšlel/a jsem o tom & 39 \\
\hline
\end{tabular}

Tab. č. 6: Nejčastějši důvody vedoucí respondenty k nezar̆azeni edukačni robotiky do výuky.

\section{Diskuse}

V září 2017 vydala Česká školní inspekce (dále jen ČŠI) tematickou zprávu popisující výsledky inspekčního elektronického zjištování zaměřeného na zmapování podmínek pro využití digitálních technologií ve výuce. Některé výsledky ČŠI potvrzují naše zjištění. V malých základních školách vyučuje ICT podle tematické zprávy ČŠI pouze 52,2 \% aprobovaných učitelů, ve velkých základních školách 43,4\%. Problémem je také nedostatek financí na školách, z čehož resultuje zastaralost výpočetní techniky a její nízká periodicita obnovy. Mezi faktory, které učitelům nejvíce brání v intenzivnějším využívání ICT ve výuce tak nejčastěji patří nedostatečné vybavení či nedostatek času. Učitelé ovšem uváděli také nedostatečné znalosti obsluhy ICT vybavení či problémy s organizací výuky. To může mnohdy souviset s absencí ICT koordinátora či technika na škole. Některé učitele odrazuje nedostatečné sebevědomí a obavy z využití nových prostředků ve výuce (ČŠI, 2017).

Kurikulum základního vzdělávání bude $\mathrm{v}$ současnosti procházet podstatnými změnami, které by měly učitelům nastavit příznivější podmínky pro využití digitálních pomůcek ve výuce. Než ale $\mathrm{k}$ těmto změnám dojde, musí se učitelé vyrovnat s aktuální, ne príiliš pozitivní situací. Naráží totiž na některé problémy, které jim znemožňují začlenění robotických stavebnic, a tedy edukační robotiky do výuky dle jejich představ. Mezi hlavní problémy patř́ dle našich zjištění př́má absence algoritmizace a programování ve výuce a kurikulu a nedostatek financí na pořízení stavebnic. Řešení těchto nedostatků slibuje SDVZ, kde se počitá s vytvářením otevřených (volně dostupných) vzdělávacích zdrojů, které mimo jiné budou přispívat $\mathrm{k}$ rozvoji digitální gramotnosti a informatického myšlení žáků. Počítá se také s vytvořením systému pravidelných inovací rámcových vzdělávacích programů, čímž se zajistí jejich pravidelná obnova v souladu s aktuálními vědeckými poznatky a vývojem $v$ oblasti digitálních technologií.

Z našich výsledků také vyplývá, že řada učitelů o existenci robotických stavebnic zatím neví anebo o jejich využití vůbec neuvažovala, což by měla řešit plánovaná metodická podpora, která usnadní integraci digitálních technologií do běžného chodu a života školy.

Problémem je také vysoké procento neaprobovaných učitelů informatiky, z nichž někteří vyučují tento předmět pouze z nedostatku učitelů na škole a bliže je tato oblast nezajímá. Česká republika se tedy dostala do podobných problémů, které byly v minulých 
letech řešeny také ve Spojených státech. Zde mezi lety 2000 a 2005 poklesl počet absolventů informatiky pro vzdělávání na některých univerzitách o $50 \%$ a bylo tedy nutné zajistit nápravu tohoto znepokojujícího stavu (Liu, Hasson, Barnett, \& Zhang, 2011). Řešení tohoto problému v České republice ovšem překračuje hranice SDVZ. V souladu se strategií bude třeba také zajistit adekvátní př́ípravu nových učitelů, kteří se budou schopni plynule zapojit do modernizované výuky. V souvislosti s edukační robotikou bude nutné učitele připravit na zvládání problémů souvisejících se začleněním tohoto tematického celku do výuky. Jedná se hlavně o výběr vhodného typu stavebnice s ohledem na věk žáků, výběr programovacího prostředí, volbu vhodného typu úloh, dispoziční řešení výuky, organizaci činností žáků či možnosti čerpání informací o této oblasti a metodickou podporu.

Příkladem úspěšného procesu začlenění edukační robotiky do výuky může být Štátný vzdělávací program Slovenské republiky, ve kterém mají ve výuce jak předmět informatika, tak i tematický celek edukační robotika podstatně důležitější roli a větší časovou dotaci. Informatika je na Slovensku vyučována jednu hodinu týdně od 3 . do 8. ročníku oproti jedné hodině na prvním a jedné hodině na druhém stupni základních škol v České republice. Již na prvním stupni základní školy nalezneme na Slovensku v obsahu učiva algoritmizaci a programování, kde se žáci učí algoritmickému řešení problému, vytvárí návody a jednoduché programy. Ve výkonovém standardu předmětu informatika se navíc uvádí, že žák by měl být schopen analyzovat problém, interaktivním způsobem navrhnout jeho řešení a řešení také sestavit. Rozvíjí se také schopnost sebereflexe. Možné řešení žák může představit kupř́íkladu v podobě sestaveného robota. Na druhém stupni žáci na své znalosti navazují a řešení problému je zde prováděno jazykem pro zápis algoritmu nebo programu. Žáci se zde naučí základní programové konstrukty - např́iklad podmínky a cykly (ŠPÚ, 2015). Potenciál pro využití robotické stavebnice pro tyto činnosti je tedy značný.

Nejčastější využití edukační robotiky našimi respondenty v předmětech informatika a technická výchova potvrzuje prováděné výzkumy, ve kterých byl právě v těchto předmětech vyhodnocen potenciál robotických stavebnic ve výuce jako největší (Eguchi, 2010; Benitti, 2012; Alimisis, 2012).

Odpovědi našich respondentů také potvrzují oblibu využívání robotických stavebnic od společnosti LEGO. Různé typy stavebnic tohoto výrobce se v minulosti dle Benitti (2011) objevovaly až v 90 \% výzkumů zaměřených na edukační robotiku a výukové aktivity. Tuto oblibu si stavebnice minimálně mezi českými učiteli uchovaly i v současnosti.

At' již z výsledků našich, či šetření ČŠI vyplývá, že učitelé se v současné chvíli potýkají s řadou problémů znemožňujících plnohodnotnější využití nejen robotických stavebnic, ale i dalších pomůcek ve výuce. Po realizaci SDVZ by tedy bylo zajímavé náš výzkum zopakovat a porovnat, $\mathrm{k}$ jakým změnám ve výuce došlo, zda se výrazně obohatilo materiální vybavení škol, jak učitelé změny hodnotí a zda se změnila také pozice a míra využití edukační robotiky ve výuce. 


\section{Závěr}

Naším cílem bylo zmapovat situaci mezi českými učiteli využívajícími ve výuce edukační robotiku v době před plánovanými kurikulárními změnami. Zaměřili jsme se na učitele základních škol a odpovídajících ročníků víceletých gymnázií, kteří využívají ve výuce robotické stavebnice. Z výsledků vyplývá, že i přes nízkou podporu ze strany kurikula se učitelé snaží nacházet cesty, jak těmito pomůckami ozvláštnit výuku různých předmětů. Nejčastěji se jedná o výuku informatiky či technické výchovy. Někteří učitelé ovšem vedou také specializované předměty zaměřené na výuku robotiky či totožně zaměřené volnočasové kroužky. Tyto učitele nalezneme po celé České republice a výjimkou nejsou ani menší města a vesnice. Dle odpovědí respondentů jsou robotické stavebnice využívány k různorodé paletě činností, která se mění v závislosti na předmětu. Mezi učiteli informatiky se ovšem nachází řada těch, kteří nemají potřebnou aprobaci pro výuku tohoto předmětu nebo jim tato oblast není blízká a nesnaží se proto v ní více rozvíjet a začleňovat nové poznatky do výuky. Řada učitelů, která se přesto pro zapojení edukační robotiky do výuky rozhodne musí řešit další problémy, z nichž nejčastější jsou finance na pořízení dostatečného počtu stavebnic či nedostatek prostoru pro jejich uplatnění ve výuce. Přes veškeré snahy o zlepšení této situace tak k nastolení optimálního stavu povede pravděpodobně ještě dlouhá cesta.

\section{Literatura}

Alimisis, D. (2012). Integrating Robotics in Science and Technology Teacher Training Curriculum. Proceedings of 3rd International Workshop Teaching Robotics, Teaching with Robotics, Integrating Robotics in School Curriculum Riva del Garda (Trento, Italy), 170-179.

Atmatzidou, S., \& Demetriadis S. (2014). How to Support Students' Computational Thinking Skills in Educational Robotics Activities. 4th International Workshop Teaching Robotics: Teaching with Robotics \& 5th International Conference Robotics in Education., 43-50.

Benitti, F. B. V. (2011). Exploring the educational potential of robotics in schools: A systematic review. Computers \& Education, 978-988.

Benitti, F. B. V. (2012). Exploring the educational potential of robotics in schools: A systematic review. Computers \& Education, 58(3), 978-988.

Česká školní inspekce (ČŠI). (2017). Využivání digitálních technologii v mateřských, základnich, středních a vyšších odborných školách: Tematická zpráva. Česká školní inspekce [online]. Dostupné z http://www.csicr.cz/cz/Dokumenty/Tematickezpravy/Tematicka-zprava-Vyuzivani-digitalnich-technologii

Eguchi, A. (2010). What is educational robotics? Theories behind it and practical implementation. D. Gibson \& B. Dodge (eds.), Proceedings of Society for Information Technology \& Teacher Education International Conference 2010, 4006-4014.

Eguchi, A. (2014). Robotics as a Learning Tool for Educational Transformation. $4^{\text {th }}$ International Workshop Teaching Robotics: Teaching with Robotics $\& 5^{\text {th }}$ International Conference Robotics in Education, 27-34.

Eguchi, A., \& Uribe L. (2017). Robotics to Promote STEM Learning: Educational Robotics Unit for 4th Grade Science. 2017 IEEE Integrated STEM Education Conference (ISEC), 186-194.

Hussain, S., Lindh J., \& Shukur G. (2006). The effect of LEGO Training on Pupils' School Performance in Mathematics, Problem Solving Ability and Attitude: Swedish Data. The 
Journal of Educational Technology \& Society. International Forum of Educational Technology \& Society, 182-194.

Kim, Ch., Kim, D., Yuan, J., Hill, R. B., Doshi P., \& Thai, Ch. N. (2015). Robotics to promote elementary education pre-service teachers' STEM engagement, learning, and teaching. Computers \& Education, 14-31.

Lindh, J., \& Holgersson T. (2007). Does lego training stimulate pupils' ability to solve logical problems? Computers \& Education, 49(4), 1097-1111.

Liu, J., Hasson, E. P., Barnett, Z. D., \& Zhang P. (2011). A Survey on Computer Science K-12 Outreach: Teacher Training Programs. 41st ASEE/IEEE Frontiers in Education Conference.

MŠMT. (2014). Strategie digitálního vzdělávání do roku 2020. Praha: Ministerstvo školství, mládeže a tělovýchovy. Dostupné z http://www.msmt.cz/file/34429/

Mubin, O., Stevens, C. J., Shahid S., Al Mahmud A., \& Dong, J. (2013). A review of the applicability of robots in education. Technology for Education and Learning.

Ospennikova, E., Ershov, M., \& Iljin, I. (2015). Educational Robotics as an Inovative Educational Technology. Procedia - Social and Behavioral Sciences, 18-26.

Štátný pedagogický ústav (ŠPÚ). (2015). Informatika - nižšie stredné vzdelávanie. Ministerstvo školstva, vedy, výskumu a športu Slovenskej republiky [online]. Štátný pedagogický ústav. Dostupné z https://www.minedu.sk/data/att/7510.pdf

Štátný pedagogický ústav (ŠPÚ). (2015). Informatika - primárne vzdelávanie. Ministerstvo školstva, vedy, výskumu a športu Slovenskej republiky [online]. Štátný pedagogický ústav. Dostupné z https://www.minedu.sk/data/att/7496.pdf

Tocháček, D., \& Lapeš, J. (2012). Edukační robotika. Praha: Univerzita Karlova, Pedagogická fakulta.

Williams, D., Ma Y., Prejean L., \& Ford M. J. (2007). Acquisition of physics content knowledge and scientific inquiry skills in a robotics summer camp. Journal of Research on Technology in Education, 40(2), 201-216.

Ziaeefard, S., Miller, M. H., Rastgaar M., \& Mahmoudian N. (2017). Co-robotics handson activities: A gateway to engineering design and STEM learning. Robotics and Autonomous Systems, 97, 40-50. 